Maurice A. Deane School of Law at Hofstra University Scholarly Commons at Hofstra Law

Hofstra Law Faculty Scholarship

2002

\title{
Voting and Political Participation
}

Grant M. Hayden

Maurice A. Deane School of Law at Hofstra University

Follow this and additional works at: https://scholarlycommons.law.hofstra.edu/faculty_scholarship

\section{Recommended Citation}

Grant M. Hayden, Voting and Political Participation The Oxford Companion to American Law 819 (2002)

Available at: https://scholarlycommons.law.hofstra.edu/faculty_scholarship/656

This Article is brought to you for free and open access by Scholarly Commons at Hofstra Law. It has been accepted for inclusion in Hofstra Law Faculty Scholarship by an authorized administrator of Scholarly Commons at Hofstra Law. For more information, please contact lawcls@hofstra.edu. 
uals have *liberty interests and *privacy rights to discretely pursue what they consider to be pleasurable. They should be free from state interference and control as long as their activities do not intrude on the rights and comfort of others.

Although the "war on drugs" rages unabated, gambling has been legalized to such an extent that the illicit forms (betting with bookmakers or backroom poker games) pale in comparison to the socially acceptable, state-promoted, and corporate-run opportunities for wagering (sweepstakes, lotteries, off-track and sports betting, and casino and Internet games of chance). Legalization has not proceeded very far for other victimless crimes. A limited number of licensed brothels operate in certain jurisdictions within Nevada, and houses of prostitution proliferate in officially designated red-light districts in many foreign cities. Coffee houses serve marijuana in Amsterdam. And drug users are not treated as criminals in many countries.

A compromise position called "harm reduction" has developed between the two extremes of vice suppression and vice acceptance. For example, the goal of harm-reduction policies for drug-taking is to minimize the collateral damage inflicted on heavy users of controlled substances, as well as on society as a whole. Strategies include methadone maintenance clinics, which dispense a substitute narcotic to heroin addicts so they will not feel compelled to steal to support their habits, and needle-exchange programs for intravenous drug injectors, who then will not share contaminated hypodermic syringes and spread AIDS to each other and their sex partners.

[See also Drugs, Illegal; Morals Offenses]

- Edwin Schur, Crimes Without Victims: Deviant Behavior and Public Policy-Abortion, Homosexuality, and Drug Addiction, 1965. Edwin M. Schur and Hugo Adam Bedau, Victimless Crimes: Two Sides of a Controversy, 1974. Alexander Smith and Harriet Pollack, Some Sins Are Not Crimes, 1975. Gilbert Geis, Not The Law's Business: Examination Of Homosexuality, Abortion, Prostitution, Narcotics and Gambling in the United States, 1979. Donal MacNamara and Andrew Karmen, Deviants: Victims Or Victimizers?, 1983. Piers Beirne and James Messerschmidt, Criminology, 3d ed., 2000.

-Andrew Karmen

VIGILANTISM. See Mob Violence and Vigilantism.

VOIR DIRE. See Jury.

VOTING AND POLITICAL PARTICIPATION. The history of voting in the United States has not been characterized by smooth and inexorable progress toward universal suffrage and widespread political participation. It has instead been much messier, littered with periods of both expansion and retraction of the franchise with respect to many groups of potential voters. Throughout this checkered history, those who controlled existing institutions had the ability to manipulate democratic processes and outcomes, and they used that ability, first and foremost, to preserve their own control. This, in turn, meant that less powerful segments of society, including racial and ethnic minorities, faced long, difficult struggles for meaningful political participation.

The *Constitution initially contained little guidance on the question of suffrage: there wàs no express right to vote, and there were few provisions that even related to the exercise of the franchise. Article I, Section 2, mandated that voters for members of the House of Representatives (the only directly elected federal body under the original Constitution) meet the same qualifications as voters for the most numerous branch of the state legislature, and Article II, Section 1, granted the states discretion to choose the procedure for selecting members of the electoral college. Under the Constitution, then, the breadth of the right to vote for both state and national elections was. fixed by state law. And at the time of ratification, this meant that many people-including most women, African Americans, Native Americans, and propertyless white men-could not vote.

The first half of the nineteenth century witnessed a dramatic expansion of the right to vote, but most of its benefits were reserved for white men. Property qualifications, already eroding at the time of the Revolution, were gradually dismantled; by 1850 , only two such requirements remained in force, and both were specifically targeted-one applied to blacks in New York and the other to foreign-born residents of Rhode Island. As property qualifications were phased out, states sometimes replaced them with tax-paying requirements, but those, too, after peaking around 1830, were swept aside in the democratic upsurge of the period. By the middle of the century, most formal economic barriers to voting had been eliminated.

This dramatic expansion of the franchise had no parallel in Europe, perhaps because upper classes in America had less to fear from a newly franchised agricultural or industrial underclass. Most agricultural labor in the United States was done by slaves, not peasants, and the slave vote was not yet an issue. Similarly, elimination of tax-paying requirements did not unleash a horde of factory 
workers as it would have in England, for America remained a largely agrarian society. Thus, the decoupling of economic status from the right to vote opened the possibility of democratic participation to a burgeoning urban population of largely middle-class men, not to lower-class factory workers, and certainly not to slaves. Indeed, the democratic expansion did not even result in the ready franchisement of existing minority groups to which it could have applied. A large number of states, as they removed the economic restrictions on voting, formally excluded free black men, and by the middle of the century, only five states (Maine, Massachusetts, New Hampshire, Rhode Island, and Vermont) did not formally discriminate against blacks.

In the middle of the nineteenth century, millions of immigrants from Asia, Ireland, and Southern and Eastern Europe began to arrive to farm, work in factories, and build the railroads. Most of the country, with the exception of some of the new Midwestern states that were hungry for settlers, was apprehensive about the prospect of immigrants at the polls. While early nativist movements achieved some success in combating immigrant electoral power, the great waves of ${ }^{*}$ immigration in the latter half of the nineteenth and early twentieth centuries provoked a more widespread reaction. Many states rejected proposals that allowed for alien suffrage, and states that had once actively courted immigrant settlers began to repeal laws that allowed certain aliens to vote. States adopted devices purportedly aimed at combating fraud-such as lengthy waiting periods and requirements that naturalized citizens show their naturalization papers to election officials before registering or voting - that discouraged or prohibited immigrants from voting. The use of literacy tests and the rise of the secret ballot (which was a de facto literacy test since it required the voter to be able to read the ballot) also took their toll on immigrant participation.

While few blacks could vote before the Civil War, the end of the conflict ushered in a brief period when black political participation flourished. The Military Reconstruction Act of 1867 required Southern states to grant the vote to all men-including recently emancipated black menas a condition of reentry into the Union. An early question about whether the Thirteenth Amendment, abolishing *slavery, formed a sufficient basis for enlarging the franchise became moot with the ratification of the ${ }^{*}$ Fourteenth and Fifteenth Amendments.

The first section of the Fourteenth Amendment addressed the subject of the black vote somewhat obliquely, granting citizenship to those born or naturalized in the United States and preventing states from depriving any person of *equal protection of the laws. The second section of the amendment confronted the subject of voting more directly, providing that any state that denied participation in state or federal elections to "any of the male inhabitants of such State, being twentyone years of age, and *citizens of the United States ... except for participation in rebellion, or other crime," should have its allocation of representatives and presidential electors proportionately reduced. This preserved the states' entitlement to discriminate with respect to voting but imposed a substantial penalty-loss of federal representation-for doing so. This second provision, though fairly specific, has never been used; the equal protection clause, however, was later the source of a tremendous amount of voting-rights jurisprudence.

With Ulysses S. Grant's narrow victory in the 1868 presidential election, the Republican Party, realizing that the black vote was critical to its future success, drafted the Fifteenth Amendment to deal with the issue of black suffrage more directly. The amendment, ratified in 1870 , guarantees that a citizen's entitlement to vote could not be "denied or abridged by the United States or by any State on account of * race, color, or previous condition of servitude." Shortly after it went into effect, Congress exercised its power to effectuate the amendment through the Enforcement Act of 1870 , which criminalized interference with the new right to vote, and the Force Act of 1871, which established the infrastructure-in the form of federal election supervisors-to ensure access to the polls.

The Southern reaction to these efforts to safeguard the black vote was swift and, at times, vicious. Some states attempted to take the bite out of the black vote: Georgia, for example, passed a statute that prohibited blacks from holding public office. There was also widespread violence. Between the April gubernatorial election and November presidential election of 1868 , Louisiana Democrats killed over a thousand people, mostly blacks.

But with the new federal legal machinery in place-and the occupying Union army to enforce it-the South witnessed a tremendous upsurge in black political participation. Moreover, with access to the polls safeguarded, black candidates experienced a marked degree of electoral success. Between 1869 and 1901, the South sent twenty blacks to the U.S. House of Representatives, and even 
produced two black senators. Although no Southern state elected a black governor, three statesLouisiana, Mississippi, and South Carolinaelected black lieutenant governors, and over seven hundred African Americans were elected to state legislatures.

The Compromise of 1877 and withdrawal of military troops marked the beginning of the end of black political participation in the South. Although the Reconstruction Amendments were still in place, the Supreme Court gutted the Enforcement Act and the Force Act in two 1876 cases, United States v. Reese and United States v. Cruikshank. These cases, combined with the withdrawal of the Union army, crippled the ability of Congress to enforce the Fifteenth Amendment against public and private incursions. Southern whites responded with a combination of force and ballotbox fraud to reduce the number of black voters and, more significantly, the impact of the black vote on elections. To the same end, Southern legislatures instituted a range of practices such as blatantly gerrymandered districts and at-large elections in areas where blacks were in the minority. As a result, while blacks continued voting in fairly substantial, though decreasing, numbers through the 1880 s, they were no longer able to elect many of their own candidates to office.

Although the Fifteenth Amendment prohibited outright race discrimination at the polls, it was not interpreted to prevent states from imposing facially neutral measures that served as proxies for race. From 1890 to 1910 , the Southern white political leadership closed the book on black voting altogether through a series of state statutory and constitutional provisions imposing devices such as poll taxes and literacy tests. Such devices were intended to prevent poor and illiterate blacks-and in Texas, Mexican Americans-from voting, and the provisions gave officials broad discretion to determine whether a particular voter met the requirements. As a result, political participation in the South plummeted; in Louisiana alone, the number of registered blacks dropped from more than 130,000 in 1896 to fewer than 1,500 by 1904 . Other Southern states were similarly successful in their efforts to disenfranchise blacks, and the Supreme Court, most notably in Giles v. Harris (1903), turned a blind eye to the problem.

Another highly effective discriminatory practice was the white primary, which involved closing the Democratic primaries-the only real election in most Southern political races--to blacks. In a series of cases out of Texas, the Supreme Court initially invalidated state-sponsored white primaries, but in Grovey v. Townsend (1935), it upheld a refinement involving the exclusion of blacks by vote at the party converition because it was sufficiently detached from state action to escape constitutional scrutiny. Grovey, though, was overruled just nine years later by a reconstituted Court in Smith v. Allwright (1944), based on the integral role of the primary in the state's voting process.

Although the end of the white primary had some positive effects on black political participation, the constitutional and statutory roadblocks erected around the turn of the century continued to keep most Southern blacks away from the polls. In the North, while more blacks registered and voted, they did not do so at the same level as whites, and recent immigrants continued to face significant obstacles to achieving meaningful representation. And while the ratification of the Nineteenth Amendment in 1920 opened the polls to women, black and immigrant women continued to face the same hurdles as their male counterparts. The relative calm of the first half of the twentieth century, though, came to an end with the momentous constitutional and statutory changes in voting-rights law in the 1960s.

Black migration from the rural South and immigration from southern and eastern Europe fueled population growth in urban areas in the early part of the twentieth century. Political boundaries, however, were not redrawn to maintain districts of roughly equal population and, as a result, the voting power of those in growing urban districts was numerically diluted while that of their rural, largely white counterparts was correspondingly concentrated. State legislatures, dominated by rural interests, refused to grant the concessions needed to achieve more equitable district sizes, and the Supreme Court was initially reluctant to intervene in what Justice ${ }^{*}$ Frankfurter termed the "political thicket" of legislative reapportionment.

The Supreme Court, however, soon entered that thicket in ${ }^{*}$ Baker v. Carr (1962), where it found unequal apportionment to be a justiciable constitutional claim. Soon thereafter, the Court mandated an equiproportional or "one person, one vote" standard for congressional districts in Wesberry v. Sanders (1964) and for state legislative districts in Reynolds v. Sims (1964). Because Reynolds required both houses of state *legislatures to be based on population, the structure of most state ${ }^{*}$ governments was dramatically altered. Baker and its progeny also resulted in a massive shift of political power from rural areas to the cities and suburbs.

After a series of ineffective attempts to open the 
political system to blacks in the South in the ${ }^{*}$ Civil Rights Acts of 1957, 1960, and 1964, Congress took a new approach in the Voting Rights Act of 1965. The act, designed to enforce the Fifteenth Amendment, quickly became one of the most successful pieces of civil rights legislation in the nation's history. Some provisions applied to the entire country. Section 2, for example, tracked the language of the Fifteenth Amendment in prohibiting voting qualifications or practices that denied or abridged the right of any citizen to vote on account of race or color. Other provisions focused on the unique problems of the South by using a neutral formula to select certain jurisdictions for special treatment; the formula captured many of the worst offenders, including Alabama, Louisiana, Mississippi, South Carolina, Virginia, and parts of North Carolina.

The "covered" jurisdictions were subject to two principal constraints. First, they were prohibited from using devices, such as literacy tests and character tests, that discriminated against minority voters. Second, they were required to submit any proposed change in election procedures-from moving the location of a polling place to wholesale redistricting-to the *attorney general or to the federal district court for the District of Columbia for "preclearance" before making the change. The Supreme Court, in Allen v. State Board of Elections (1969), gave a broad interpretation to the preclearance section, finding that it included changes that diluted black votes as well as those that disenfranchised black voters. Changes would only be approved if they did not have the purpose or effect of abridging the right to vote on the basis of race. This essentially meant that any change in voting procedure in the covered jurisdictions, including those involving attempts to evade the purpose of the act, had to go through Washington.

The Voting Rights Act of 1965 had an immediate and lasting effect on black political participation in the South. Within the space of a couple of years, the percentage of eligible blacks registered in the covered jurisdictions rose from an average of 29 percent to over 52 percent. The initial gains were most dramatic in the jurisdictions of some of the worst offenders: in Mississippi, for example, black registration rose from a disgraceful 6.7 percent in 1964 to nearly 60 percent in 1968. And, over the next several decades, black voter participation continued its upward climb, slowly reducing the gap between white and black voter registration.

In the years after its passage, the Voting Rights Act of 1965 was extended and strengthened. As part of its reauthorization in 1970 , the ban on literacy and character tests was extended nationwide. In 1975, the Act was amended to provide protection to foreign-language minorities, and has been used quite successfully on behalf of Hispanic voters. Thus, while the Voting Rights Act originally targeted the problem of black political participation in the South, it has since been extended to protect most racial and ethnic minorities in all jurisdictions.

The Voting Rights Act, however, was not the only significant legal change that cleared the way for minority political participation. The TwentyFourth Amendment, ratified in 1964, barred the use of poll taxes.in federal elections; the Supreme Court followed suit in Harper v. Virginia Board of Elections (1966), prohibiting their use in state elections. More significantly, the Fourteenth and Fifteenth Amendments were used to challenge districting schemes and other devices that, while not denying minority voters access to the polls or numerically diluting their votes, nonetheless hindered their ability to participate and elect representatives of their choice. In White v. Regester (1973), for example, the Supreme Court found that use of multimember state legislative districts in Texas violated the equal protection rights of black and Hispanic voters by diluting their voting power. The multimember districts in question, the court found, were used to submerge the minority voters in a sea of white voters, effectively precluding them from electing their preferred representatives.

These "qualitative" vote dilution claims (as opposed to the "quantitative" claims involving numerical dilution) were soon expanded to other, more ingenious districting schemes. Most litigation under the Constitution, though, ground to a halt when the Supreme Court found in City of Mobile v. Bolden (1980) that a party alleging qualitative vote dilution under the Fourteenth or Fifteenth Amendments must demonstrate that the challenged procedure was established or maintained with discriminatory intent. The Bolden decision, however, set off a storm of protest that culminated in passage of an amendment to Section 2 of the Voting Rights Act when it came up for reauthorization in 1982. The amendment decoupled Section 2 claims from constitutional claims of vote dilution, and śpecifically eliminated the requirement of discriminatory intent. As amended, Section 2 has become the weapon of choice in voting rights litigation.

The development of the Voting Rights Act and aggressive use of its preclearance requirements by 
the Justice Department in the 1990s led to creation of a number of districts in which minority groups comprised an effective majority of the voting-age population. While these majority-minority districts proved crucial to ensuring the electoral success of minority candidates, the future of such districts was dealt a blow by Shaw v. Reno (1993), in which the Supreme Court allowed white voters to challenge the constitutionality of a majority-black Congressional district in North Carolina with a "bizarre" shape. Writing for a 5-4 majority, Justice O'Connor found the proposed district so irrational on its face that it could only be understood as an attempt to segregate voters based on race.

The Court clarified the Shaw standard in Miller v. Johnson (1995). While not outlawing majorityminority districts per se, the Court. promoted a colorblind view of the districting process by insisting that race could not be the predominant factor in drawing district lines. But, given that race is strongly correlated with political party preference in the United States, the impact of these recent opinions may be lessened as plaintiffs find it difficult to prove that race, and not party affiliation, is the predominant consideration in redistricting decisions.

Although racial and ethnic minorities now experience greater opportunities for political expression than at many other times in the nation's history, there are still significant legal roadblocks to more widespread participation. Most. states, for example, prohibit those convicted of serious crimes from voting, many for the period of incarceration, and some for life. Such restrictions are estimated to keep about four million people from the polls, and because some groups experience higher rates of conviction and incarceration, a disproportionate number of them are black and His- panic. Nationwide, 14 percent of black men are disenfranchised by such laws; in some states, such as Alabama and Florida, almost one in three black men is barred from the polls. Immigrants, too, continue to fight an uphill battle. Millions of legal and illegal aliens fully participate in the economic and social life of the nation, but are barred from participating in its political life by requirements that they be citizens in order to cast a ballot. Such rules, like many throughout our history, are neutral on their face with respect to race and ethnicity, but clearly impede the ability of many minority groups to express their preferences at the polls and illustrate the continuing challenge they face in their struggle to fully participate in our political institutions.

[See also Governance]

- Chilton Williamson, American Suffrage: From Property to Democracy, 1760-1860, 1960. William Gillette, The Right to Vote: Politics and the Passage of the Fifteenth Amendment, 1965. Robert B. McKay, Reapportionment: The Law and Politics of Equal Representation, 1965. Marchette G. Chute, The First Liberty: A History of the Right to Vote in America, 1619-1850, 1969. J. Morgan Kousser, The Shaping of Southern Politics: Suffrage Restriction and the Establishment of the One-Party South, 1880-1910, 1974. Steven F. Lawson, Black Ballots: Voting Rights in the South, 1944-1969, 1976. Bernard Grofman, Lisa Handley, and Richard G. Niemi, Minority Representation and the Quest for Voting Equality, 1992. Chandler Davidson and Bernard Grofman, eds., Quiet Revolution in the South: The Impact of the Voting Rights Act, 19651990, 1994. Keith Reeves, Voting Hopes or Fears?: White Voters, Black Candidates Racial Politics in America, 1997. J. Morgan Kousser, Colorblind Injustice: Minority Voting Rights and the Undoing of the Second Reconstruction, 1999. Alexander Keyssar, The Right to Vote: The Contested History of Democracy in the United States, 2000. 